\title{
Genetic and Phenotypic Heterogeneity in Disorders of Peroxisome Biogenesis-A Complementation Study Involving Cell Lines from 19 Patients
}

\author{
ADELBERT A. ROSCHER, SIGRID HOEFLER, GERALD HOEFLER, EDUARD PASCHKE, \\ FRITZ PALTAUF, ANN MOSER, AND HUGO MOSER
}

\begin{abstract}
Department of Clinical Chemistry, Pediatric Clinic, University of Munich, Lindwurmstrase 4, 8000 Munich, Germany [A.A.R.]; Kennedy Institute and Departments of Neurology and Pediatrics, Johns Hopkins University, Baltimore, MD 21205 [S.H., G.H., A.M., H.M.]; Pediatric Clinic, University of Graz, Auenbruggerplatz A-8036 Graz, Austria [E.P.]; and Department of Biochemistry, Technical University Graz, Schloegelgasse 9, A-8010 Graz, Austria [F.P.]
\end{abstract}

\begin{abstract}
Disorders of peroxisomal biogenesis include the Zellweger syndrome, neonatal adrenoleukodystrophy, infantile Refsum syndrome, and hyperpipecolic acidemia. These names were assigned before the recognition of the peroxisomal defect and the distinction between phenotypes is uncertain. Recent studies have identified at least four complementation groups, and indicate the presence of at least that number of distinct genotypes. The purpose of the present study was to examine the relationship between genotype and phenotype. We studied cultured skin fibroblasts from 19 patients in whom deficiency of peroxisomes had been established. Complementation analysis was performed with the criterion of complementation being the restoration of the capacity to synthesize plasmalogens when fibroblasts from two patients were fused. Six complementation groups were identified, and consisted of one 13 member group, one two member group, and four groups comprising single cases. The phenotype of each group was examined with respect to age of survival, clinical manifestations, and biochemical alterations. The 13 member group included patients with all of the four currently designated phenotypic entities, while the most common phenotype (Zellweger syndrome) was distributed among five of the six groups. We conclude that the currently used clinical categories do not represent distinct genotypes. Apparently different genes code for a similar phenotype and one defective gene may lead to variant phenotypes. Definitive classification and understanding of these disorders await definition of the specific biochemical defect in each of the genotypes. (Pediatr Res 26: 67-72, 1989)
\end{abstract}

\section{Abbreviation}

ALD, adrenoleukodystrophy

There exist a group of genetically determined disorders in which the principal abnormality is the absence or diminution in

Received December 1, 1988; accepted March 13, 1989.

Correspondence Hugo W. Moser, M.D., The Kennedy Institute, Baltimore, MD 21205.

Supported in part by Grant HD 10981 from the U.S. Public Health Service. G.H. was supported by Fonds zur Foerderung der Wissenschaftichen Forschung, Project J0145M. S.H. was supported by a Fulbright Scholarship. the number of morphologically detectable peroxisomes $(1,2)$. Peroxisomal proteins are synthesized on free polyribosomes, released in the cytosol, and then targeted to preexisting peroxisomes (3). Recent studies involving cultured skin fibroblasts from four patients $(4,5)$ indicate that a defect in targeting mechanisms represents the primary abnormality in several and perhaps all of these peroxisomal deficiency disorders.

The Zellweger cerebro-hepato-renal syndrome was the first disorder in which an absence or deficiency of peroxisomes was recognized (6). Patients with classical Zellweger syndrome display characteristic dysmorphic features, eye abnormalities, profoundly disordered neuronal migration and demyelination, renal cysts, patellar calcific stippling, and liver disease. Psychomotor development is virtually absent and most infants die in the first few months of life (7). Biochemical studies have shown a "panel" of abnormalities. These include cytosolic localization of catalase; the impaired capacity to degrade very long chain fatty acids, phytanic acid, and pipecolic acid; and defective synthesis of plasmalogens and bile acids $(1,2)$.

More recently it has been shown that peroxisomal deficiency and the abnormalities cited above also are found in somewhat less severe disease states that may be compatible with survival to the mid-teens or later. Currently such patients are designated as having neonatal adrenoleukodystrophy (8), hyperpipecolic acidemia (9), or infantile Refsum disease (10). These names were assigned originally on the basis of a single biochemical abnormality that was thought to be the sole biochemical manifestation. These concepts had to be revised totally when it was recognized that all of these disorders have the full panel of biochemical abnormalities. The relationship between the Zellweger syndrome and the milder disorders is unclear. Possibly most or all of the differences represent a gradation of severity, with Zellweger syndrome the most severe; infantile Refsum the least severe, and neonatal ALD intermediate $(11,12)$. For reasons discussed elsewhere, hyperpipecolic acidemia is no longer viewed as a separate phenotype, and depending upon severity is assigned to the Zellweger or neonatal ALD category (12).

The challenge to the understanding and classification of the disorders of peroxisome biogenesis has been intensified by recent complementation studies conducted by Brul et al. (13) and in our laboratory (14). In complementation analysis, somatic cells derived from patients with the apparent same metabolic defects, but clinically different phenotypes, are induced to fuse. The resulting multinuclear cells are examined for their ability to carry out normal metabolic functions (15). Restoration of activity can 
only occur if each parental cell provides the gene defective in the other. These studies have identified at least five distinct complementation groups and this finding has led to the conclusion that this group of disorders comprises at least an equal number of distinct genotypes.

During the last 5 y our laboratory has studied samples from 261 patients with disorders of peroxisomal biogenesis. The purpose of our study is to examine the relationship between phenotype and genotype. We have performed complementation studies in cultured skin fibroblasts from 19 thoroughly documented patients who represent the broad range of phenotypic variation.

\section{MATERIALS AND METHODS}

Patient selection. In all patients included in this study $95 \%$ or more of catalase activity in cultured skin fibroblasts was recovered in the cytosolic fraction (5), compared with less than 5\% in control cell lines. Experience in our laboratory (Watkins PA, unpublished observation) indicates that cytosolic localization of catalase in cultured skin fibroblasts is associated with a lack or diminution of demonstrable peroxisomes in the liver. Electron microscopic studies of liver biopsy or autopsy specimens (16) were available in only five patients. The previously cited panel of biochemical abnormalities were present in all instances in which these tests were performed.

Table 1 lists the major clinical findings of the patients included in the study, as well as the diagnostic label assigned in accordance with current criteria. Patients who had the characteristic dysmorphic features (7), chondrodysplasia punctata and renal cysts were assigned to the classical Zellweger syndrome category. The history and biochemical findings of one of these cases have been reported (17). The diagnosis of neonatal ALD was applied to patients who had less striking or no dysmorphic features, and who lacked chondrodysplasia punctata or demonstrable renal cysts. Neonatal ALD cases N1, N2, N3, N8, respectively, are cases 7, 1,5, and 6 in Reference 8 and N7 is the case reported in Reference 18. The patient with hyperpipecolic acidemia has been reported by Thomas et al. (19). Case N5 had presented as Leber congenital amaurosis and was subsequently assigned to the neonatal ALD category by Ek et al. (20). We diagnosed infantile Refsum syndrome in two more mildly involved patients who had achieved psychomotor milestones even though all were moderately or severely retarded. One of these patients (I2, Table 1) who was described previously (Ref. 21 , case 1) also had retinitis pigmentosa, hearing deficits, and elevated levels of phytanic acid in plasma. The sample selected for this study is representative of the 261-member cohort of patients with disorders of peroxisomal biogenesis tested in our laboratory, except that we included a larger proportion of more mildly involved patients since we wished to encompass the full phenotype range.

Materials. Cell culture reagents were from GIBCO Laboratories (Grand Island, NY). $\left[1-{ }^{14} \mathrm{C}\right]$ Hexadecanol $(11.4 \mathrm{mCi} / \mathrm{mmol})$ was obtained from Amersham Corp. (Arlington Heights, IL), and $\left[9^{\prime}, 10^{\prime}{ }^{3} \mathrm{H}\right]$-sn-hexadecylglycerol $(5.5 \mathrm{mCi} / \mathrm{mmol})$ was prepared by chemical synthesis (22). Ficoll 400 was obtained from Pharmacia Fine Chemicals (Piscataway, NJ) and polyethylene glycol 4000 from Merck (Rahway, NJ). All other reagents were of analytical grade and were obtained from commercial sources.

Biochemical assays of peroxisomal function. Catalase was assayed by the method of Peters et al. (23). The subcellular distribution of catalase was measured in digitonin-treated fibroblasts as previously described (17). Protein was determined by the

Table 1. Clinical findings in patients with disorders of peroxisomal biogenesis [cases are listed by complementation groups (1-6) and by diagnostic label]*

\begin{tabular}{|c|c|c|c|c|c|c|c|c|c|c|c|c|c|c|c|c|c|c|c|c|}
\hline Patients & $\mathrm{Zl}$ & $\mathrm{Z} 2$ & $\mathrm{Z3}$ & Z4 & $\mathrm{N} 1$ & N2 & N3 & N4 & N5 & N6 & I1 & $\mathrm{I} 2$ & $\mathrm{H} 1$ & $\begin{array}{c}\text { Group I } \\
\text { patients } \\
\text { showing } \\
\text { feature } \\
(\%)\end{array}$ & $\mathrm{N} 7$ & $\mathrm{Z} 5$ & Z6 & $\mathrm{Z7}$ & Z8 & N8 \\
\hline Complementation group & 1 & 1 & 1 & 1 & 1 & 1 & 1 & 1 & 1 & 1 & 1 & 1 & 1 & & 2 & 2 & 3 & 4 & 5 & 6 \\
\hline Sex & $\mathrm{F}$ & $F$ & M & $\mathrm{F}$ & $\mathrm{M}$ & $\mathrm{F}$ & M & M & M & $\mathrm{M}$ & $\mathrm{F}$ & M & M & & $\mathrm{F}$ & M & $\mathrm{M}$ & $\mathrm{F}$ & $\mathrm{M}$ & $\mathrm{F}$ \\
\hline Age at death (mo) & 5 & 1 & 15 & 9 & & 30 & 72 & 24 & & & & & 24 & & 4 & 1 & 3 & 3 & 1 & 54 \\
\hline Last known survival (mo) & & & & & 82 & & & & 79 & 54 & 46 & 45 & & & & & & & & \\
\hline \multicolumn{21}{|l|}{ Dysmorphism } \\
\hline Large fontanelle & 1 & 1 & 1 & 1 & 1 & 1 & 1 & $X$ & 0 & 1 & 1 & $\mathrm{X}$ & 1 & 91 & $\mathrm{X}$ & 0 & 0 & 0 & $\mathrm{X}$ & 0 \\
\hline High forehead & 1 & $\mathrm{X}$ & 1 & 1 & 1 & $\mathrm{X}$ & 0 & 1 & 0 & $\mathrm{X}$ & $\mathrm{X}$ & 1 & $\mathrm{X}$ & 86 & 0 & 0 & 0 & 0 & 0 & $\mathrm{X}$ \\
\hline Broad nasal bridge & 1 & 1 & 1 & 1 & 0 & 1 & 1 & 1 & 0 & 1 & 1 & 1 & $\mathrm{X}$ & 83 & 0 & 1 & 1 & 1 & 1 & 0 \\
\hline Epicanthus & 1 & $X$ & 1 & 1 & $X$ & 1 & 0 & 1 & 0 & 1 & 1 & $\mathrm{X}$ & 0 & 70 & 0 & 1 & 1 & 1 & 1 & $\mathrm{X}$ \\
\hline Micrognathia & 1 & $\mathrm{X}$ & 1 & 1 & 0 & $\mathrm{X}$ & 0 & 0 & 0 & $X$ & $\mathrm{X}$ & 1 & 1 & 56 & 0 & 1 & 1 & $X$ & $\mathrm{X}$ & $\mathrm{X}$ \\
\hline External ear deformity & 1 & $\mathrm{X}$ & 1 & 0 & 1 & $\mathrm{X}$ & 1 & 0 & 0 & $X$ & $\mathrm{X}$ & $\mathrm{X}$ & 0 & 50 & 0 & 1 & 0 & $\mathrm{X}$ & $\mathrm{X}$ & 1 \\
\hline High arched palate & 0 & 1 & 1 & 1 & 0 & 1 & 0 & 0 & 0 & $\mathrm{X}$ & 0 & 1 & $\mathrm{X}$ & 45 & 0 & 1 & 1 & 1 & $\mathrm{X}$ & 0 \\
\hline Shallow orbital ridge & $X$ & $\mathrm{X}$ & 1 & 1 & $\mathrm{X}$ & $\mathrm{X}$ & 0 & 0 & 0 & $X$ & $\mathrm{X}$ & $\mathrm{X}$ & $\mathrm{X}$ & 40 & 0 & 1 & $X$ & $\mathrm{X}$ & $\mathrm{X}$ & $\mathrm{X}$ \\
\hline Webbed neck & $X$ & $\mathrm{X}$ & X & 1 & 0 & $\mathrm{X}$ & $\mathrm{X}$ & 0 & $\mathrm{X}$ & $\mathrm{X}$ & $\mathrm{X}$ & $X$ & $\mathrm{X}$ & 33 & 0 & 0 & 1 & $\mathrm{X}$ & $\mathrm{X}$ & $\mathrm{X}$ \\
\hline \multicolumn{21}{|l|}{ Eye } \\
\hline Retinal d & $\mathrm{X}$ & $\mathrm{X}$ & 1 & 1 & 1 & 1 & 1 & $\mathrm{X}$ & 1 & 1 & 1 & 1 & 1 & 100 & 0 & $\mathrm{X}$ & 0 & 1 & $\mathrm{X}$ & 1 \\
\hline Optic nerve dysplasia & $\mathrm{X}$ & $\mathrm{X}$ & $X$ & 0 & 0 & 1 & 1 & 1 & 1 & 1 & 0 & 0 & 1 & 60 & 1 & $\mathrm{X}$ & 0 & 0 & $\mathrm{X}$ & 1 \\
\hline Cataract & $\mathrm{X}$ & $\mathrm{X}$ & $\mathrm{X}$ & 0 & 0 & 0 & 1 & $\mathrm{X}$ & 0 & $\mathrm{X}$ & 0 & 0 & $X$ & 14 & 0 & $\mathrm{X}$ & 1 & 1 & 0 & 0 \\
\hline Corneal clouding & 0 & 1 & 0 & 0 & 0 & 0 & $\mathrm{X}$ & $X$ & 0 & $\mathrm{X}$ & 0 & 0 & $X$ & 11 & 0 & 1 & 0 & 1 & 1 & $\mathrm{X}$ \\
\hline Nystag & 1 & $X$ & 0 & $X$ & 1 & 1 & 1 & $\mathrm{X}$ & $\mathrm{X}$ & 1 & 1 & $\mathrm{X}$ & 1 & 88 & 1 & $\mathrm{X}$ & 1 & 1 & $\mathrm{X}$ & 1 \\
\hline Hepatomegaly & 1 & 1 & 1 & 1 & 1 & 0 & 0 & 1 & 1 & 1 & 1 & 1 & 1 & 85 & 0 & 1 & 1 & 1 & 0 & 1 \\
\hline Loss of skills & 0 & $\mathrm{X}$ & 1 & $X$ & 1 & 1 & 1 & 1 & 1 & 0 & 1 & $\mathrm{X}$ & 1 & 80 & 0 & $\mathrm{X}$ & $\mathrm{X}$ & $\mathrm{X}$ & $\mathrm{X}$ & 1 \\
\hline Convulsions & 1 & $\mathrm{X}$ & 1 & 1 & 1 & 1 & 1 & 1 & 0 & 0 & 0 & 1 & $X$ & 73 & 1 & 1 & 1 & 1 & 1 & 1 \\
\hline Kidney cysts & 1 & 1 & $\mathrm{X}$ & $\mathrm{X}$ & $X$ & $X$ & $\mathrm{X}$ & 0 & $\mathrm{x}$ & $\mathrm{x}$ & $\mathrm{x}$ & $\mathrm{X}$ & $\mathrm{X}$ & 67 & $\mathrm{x}$ & $\mathrm{X}$ & 1 & $\mathrm{X}$ & 1 & $\mathrm{X}$ \\
\hline Cryptorchism & 0 & 1 & $X$ & $X$ & $X$ & 1 & $\mathrm{X}$ & $\mathrm{X}$ & 0 & 1 & $\mathrm{X}$ & $\mathrm{X}$ & $\mathrm{X}$ & 60 & 1 & $\mathrm{X}$ & $\mathrm{X}$ & $\mathrm{X}$ & $\mathrm{X}$ & 0 \\
\hline Polymicrogyria & $\mathrm{X}$ & $\mathrm{X}$ & 1 & $\mathrm{X}$ & 0 & 1 & 0 & $X$ & 1 & $X$ & $\mathrm{X}$ & $X$ & $\mathrm{X}$ & 60 & $\mathrm{X}$ & 1 & 1 & $\mathrm{X}$ & 1 & $\mathrm{X}$ \\
\hline Calcification & 1 & $\mathrm{X}$ & 1 & 1 & 0 & $\mathrm{X}$ & 0 & $X$ & 0 & 0 & 0 & $\mathrm{X}$ & $\mathrm{X}$ & 38 & 0 & 1 & 1 & 1 & $\mathrm{X}$ & $\mathrm{X}$ \\
\hline
\end{tabular}

*0, absent; 1, present; X, unknown; Z, Zellweger syndrome; N, neonatal ALD; I, infantile Refsum disease; H, hyperpipecolic acidemia. 
method of Lowry et al. (24) or by the method of Bradford (25). Concentrations of very long chain fatty acids in fibroblasts and plasma were measured by gas-liquid chromatography as previously described $(26,27)$. The steps of plasmalogen biosynthesis in peroxisomes were assessed by the method of Roscher et al. (28). This method uses a double-label, double-substrate incubation. The peroxisomal component of plasmalogen biosynthesis is measured by the incorporation of $\left[1-{ }^{14} \mathrm{C}\right]$ hexadecanol into plasmalogens and compared with the microsomal component, assessed by the rate of incorporation of $\left[9^{\prime}, 10^{\prime}-{ }^{3} \mathrm{H}\right]$ hexadecylglycerol into plasmalogens.

Cell fusion. Cells were fused in the presence of polyethylene glycol (29). Two parental cell lines $\left(2 \times 10^{6}\right.$ cells each) were seeded in $75-\mathrm{cm}^{2}$ flasks in a 1:1 ratio. The next day the confluent monolayer was washed once with Hanks' balanced salt solution and treated with a solution consisting of $42 \%$ polyethylene glycol and $15 \%$ dimethylsulfoxide in minimum essential medium (Eagle) supplemented with $10 \%$ FCS for 90 s followed by addition of $42 \%$ polyethylene glycol in Hanks' balanced salt solution for another $90 \mathrm{~s}$. Then $40 \mathrm{ml}$ of Hanks' solution were added for 2 min, the mixture was removed and the cells were washed three times with Hanks' solution and cultured overnight.

To demonstrate the effects of fusion most effectively, we separated multikaryons from monokaryons. We used a modification of the method of Nelson and Carey (30). Cells were harvested and layered on top of a stepped density gradient at 1 $\mathrm{U}$ of gravity ( $5 \mathrm{ml}$ each of $2.5,5,10,12.5,15 \%$ w/vol Ficoll 400 in minimum essential medium supplemented with $10 \%$ FCS). After $3 \mathrm{~h}$, monokaryons $(2.5 \%$ fraction $=$ fraction $\mathrm{I})$ and multinuclear cells $(12.5 \%$ fraction $=$ fraction II) were collected. Intermediate fractions consisting of a mixed population of cells were discarded. After three washes with Hanks' balanced salt solution, cells in fraction I and II were recultivated and plasmalogen synthesis was measured as described (28) after a 20 -h recovery period. After each fusion aliquots of the two fractions were stained with Giemsa and examined under the microscope. This permitted distinction between "clumped" mononuclear cells and multinucleate fused cells. Fraction I contained $>98 \%$ mononuclear cells, serving as coculture-control. In all of the studies reported here at least $80 \%$ of the cells in fraction II were multinucleate.

Restoration of plasmalogen synthesis was used as the criterion for complementation. Fusion of combinations of cell lines was performed until 1) no correction could be found and the assignment to the same complementation group could be established or 2) correction with each of the groups could be found and the independence of the genetic defect could be ascertained.

Selection of cell lines for complementation studies. We first tested for complementation between cell lines from patients with widely varied phenotypes. However, as studies progressed we also noted complementation in cell lines from patients with similar phenotypes, and as shown under "Results," we demonstrated the existence of one large and five small complementation groups. Because the availability of samples and time constraints made it impractical to perform assays required to test for complementation among all cell lines, we devised a test strategy that would provide reasonably secure confirmation of these groupings. In accordance with this design, a cell line was assigned to the large group if it were shown not to complement with two other members of this same group, except that lines N1, N2, and I2 were tested against only one line. In addition, each member of the small groups was shown to complement at least one member of each of the other groups.

\section{RESULTS}

Plasmalogen synthesis was measured in monokaryotic cells recultivated from fraction I of the gradient (equivalent to coculture but having undergone the same treatment as fused cells) and in cells from fraction II with a fusion efficiency of 80 to $90 \%$ (Table 2). Values in Figure 1 are expressed as percent of the mean plasmalogen synthesis in control cells $(n=28)$. Figure 1 and Table 3 display the six complementation groups that have been established. Each complementation assay gives the plasmalogen synthesis capacity before and after fusion. The numbers above the diagonal represent co-cultured cells, those below this line, fused cells. For combinations of cell lines that do not complement (indicated by a dashed line) the plasmalogen synthesis did not exceed values expected for cocultivation. A substantial increase or complete restoration to normal values was taken as evidence of complementation and is indicated by a solid line. Fusion of control or disease cells with themselves did not affect the respective rates of plasmalogen synthesis and fusion of control with disease cells resulted in restoration of normal synthesis. Because we assume that each of the complementation groups represents a distinct genotype, we have correlated the information in Table 1 and Figure 1 to determine the relationships between genotype and phenotype. We have used two approaches to evaluate phenotype. The first approach is to correlate genotype with the diagnostic label assigned by the traditional criteria described above. Inspection of Figure 1 suggests that with this approach there is no discernible correlation between genotype and phenotype. All phenotypes are represented in group 1 whereas the most common and consistent phenotype (classical Zellweger syndrome) also occurs in four of the other groups.

Because the current phenotype-based diagnostic labels are somewhat arbitrary and not universally accepted, we developed a second approach in which we attempted to discriminate between the different complementation groups by focusing on certain key phenotypic features. Most of the clinical manifestations did not differ among the six groups. In respect to dysmorphic features, in group 1 there was a wide range from no dysmorphic features to dysmorphism in every listed criterion. One patient in group 2 lacked dysmorphic features (18), whereas the other met almost all of the criteria for Zellweger syndrome. Retinal degeneration was present in all group 1 patients for whom information was available, although it was absent in one case of group 2 and in the single case of group 3 and present in group 4 and 6 (single cases). Only one of the group 1 patients showed cataracts and one had corneal clouding, but corneal clouding was found in one case of group 2 and in the single patients of groups 4 and 5, and cataracts occurred in the single patients of groups 3 and 4 . Kidney cysts, commonly regarded as a classical Zellweger syndrome characteristic, are listed as present in Table 1 only when confirmed by autopsy, and information is limited since most of the milder cases are still alive and pathologic examinations were not performed in all patients who died. Figure 2 shows that patients in groups $2-5$ died during the first 4 mo of life, whereas the majority of patients in group 1 and the patient in group 6 survived longer. Plasmalogen synthesis was generally less affected in group 1 (Fig. 3) except in patients $\mathrm{Z1}, \mathrm{Z2}$, and Z4. Interestingly, those three patients showed the earliest age of death in this group. Patients N7 (group 2) and N8 (group 6) showed a milder deficiency of plasmalogen synthesis whereas in the remaining patients in groups 2 to 5 it was severely impaired. Levels of very long chain fatty acids in plasma and fibroblasts (Fig. 4) were slightly higher in patient Z5 (group 2) and patients in group 3 and 4 than in those of group 1 . There was no correlation between hexacosenoic (C26:1) levels and complementation groups (data not shown). When correlated with age at death, markedly elevated very long chain fatty acid levels and severely impaired plasmalogen synthesis are the strongest indicators of severe illness. Nevertheless, they cannot be used to predict the assignment of an individual case to a complementation group.

\section{DISCUSSION}

In this study we have used complementation studies to identify six distinct genotypes among the disorders of peroxisomal biogenesis and have compared genotype with phenotype. The sig- 
Table 2. De novo plasmalogen biosynthesis*

\begin{tabular}{|c|c|c|c|c|c|c|c|}
\hline & \multicolumn{3}{|c|}{$\begin{array}{c}\text { Unfused cells } \\
\text { (mononuclear cells) }\end{array}$} & \multicolumn{3}{|c|}{$\begin{array}{c}\text { Fused cells } \\
\text { (multinuclear celis) }\end{array}$} & \multirow[b]{2}{*}{ Complementation } \\
\hline $1: 1$ & $(3 \mathrm{H})$ & $(14 \mathrm{C})$ & $\begin{array}{c}\text { Ratio } \\
(14 \mathrm{C} / 3 \mathrm{H})\end{array}$ & $(3 \mathrm{H})$ & $(14 C)$ & $\begin{array}{c}\text { Ratio } \\
(14 \mathrm{C} / 3 \mathrm{H})\end{array}$ & \\
\hline $\mathrm{CO} \times \mathrm{CO}$ & 9.10 & 19.52 & 2.14 & 7.02 & 15.80 & 2.25 & - \\
\hline $\mathrm{ZS} \times \mathrm{ZS}$ & 11.49 & 1.21 & 0.11 & 8.67 & 0.98 & 0.11 & - \\
\hline NALD $\times$ NALD & 7.95 & 2.26 & 0.28 & 9.04 & 2.53 & 0.28 & - \\
\hline $\mathrm{ZS} \times \mathrm{CO}$ & 10.55 & 11.28 & 1.07 & 6.43 & 14.47 & 2.25 & + \\
\hline $\mathrm{NALD} \times \mathrm{CO}$ & 8.89 & 13.22 & 1.49 & 5.58 & 12.68 & 2.27 & + \\
\hline $\mathrm{ZS} \times \mathrm{NALD}$ & 11.58 & 5.13 & 0.44 & 6.87 & 14.35 & 2.09 & + \\
\hline
\end{tabular}

* Values represent radioactivity in plasmalogens as percent of total incorporated into phospholipids. Incorporation of the ${ }^{14} \mathrm{C}$ precursor measures peroxisomal and ${ }^{3} \mathrm{H}$ microsomal steps of plasmalogen synthesis (26). Restoration of $14 \mathrm{C} / 3 \mathrm{H}$ to normal occurs in complementing cell lines. CO, control; NALD = neonatal adrenoleukodystrophy; ZS, Zellweger syndrome.

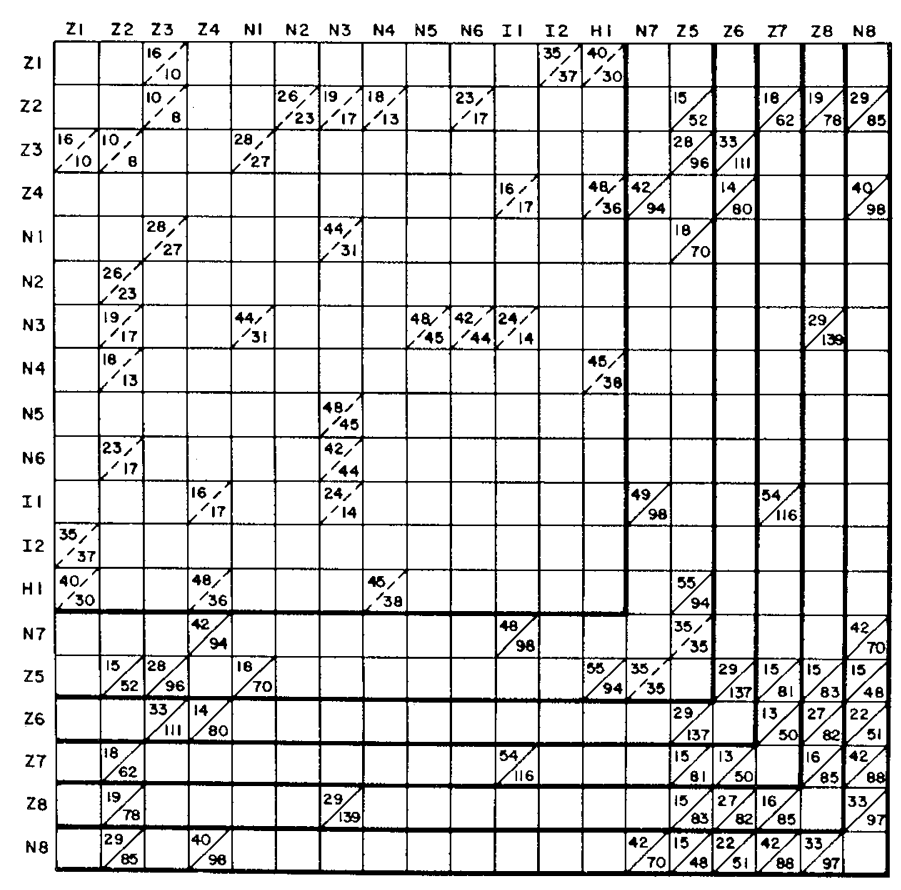

Fig. 1. Complementation analysis in patients with disorders of peroxisomal biogenesis. Values are expressed as percentage of plasmalogen synthesis in control cells $(100 \%, n=28)$. Numbers above the diagonal line represent cocultured cells, those below the line, fused cells. Complementation is indicated by a solid line. Six complementation groups were found and are separated by bold lines.

Table 3. Phenotypes in various complementation groups

\begin{tabular}{ccl}
\hline Group & $n$ & \multicolumn{1}{c}{ Phenotype } \\
\hline 1 & 13 & $\begin{array}{l}\text { Zellweger, neonatal ALD, infantile Refsum, } \\
\text { hyperpipecolic acidemia }\end{array}$ \\
2 & 2 & $\begin{array}{l}\text { Zellweger, neonatal ALD } \\
3\end{array}$ \\
4 & 1 & Zellweger \\
5 & 1 & Zellweger \\
6 & 1 & Zellweger \\
& 1 & Neonatal ALD \\
\hline
\end{tabular}

nificant finding is that there is no discernible correlation: all known phenotypes are represented within the large complementation group, although the most common phenotype is dispersed among five of the six groups. These findings indicate that the historically based nomenclature fails to delineate genotypes. Possibly these phenotypic differences reflect differences in the degree of the impairment of peroxisomal biogenesis, with Zellweger syndrome being the most severe, neonatal ALD intermediate,

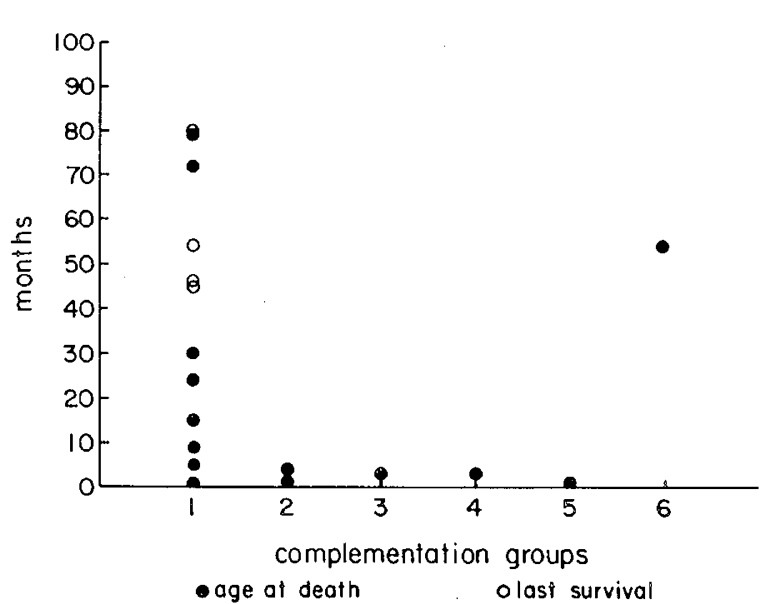

Fig. 2. Age at death or age of last known survival of patients in each complementation group (1-6).

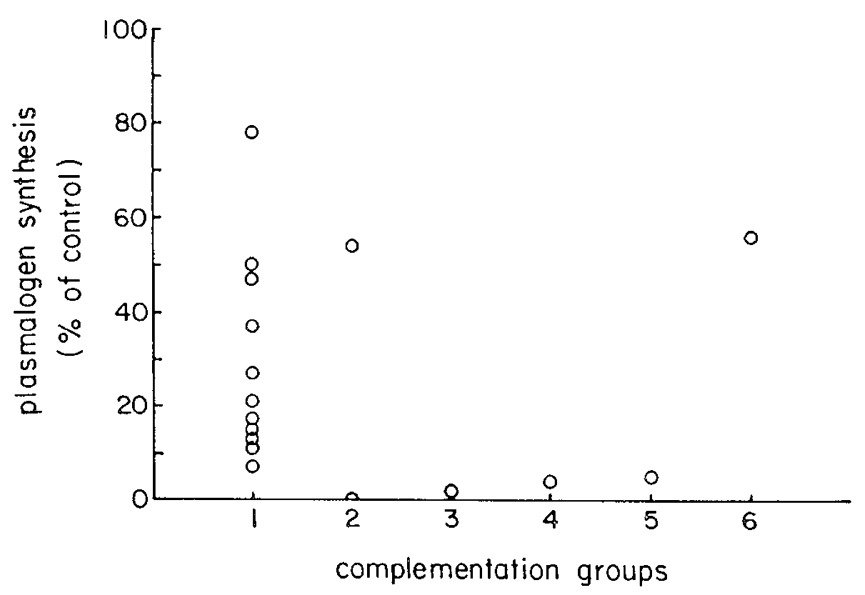

Fig. 3. Plasmalogen synthesis in fibroblasts of patients in each complementation group (1-6).

and infantile Refsum the least severe. Evidence for this point of view was first presented by Arias et al. (11). The results reported here, and those of Brul et al. (13), indicate the existence of at least six distinct genotypes. Phenotype analysis, at least as currently practiced, does not permit their identification.

The complementation assays reported here were based upon the restoration of the capacity to synthesize plasmalogens. Other criteria of complementation can also be used. Brul et al. (13) have demonstrated that subcellular catalase becomes particulate (i.e. peroxisomal) in those fused cell lines that increase their level of dihydroxyacetone phosphate acyltransferase, the peroxisomal 


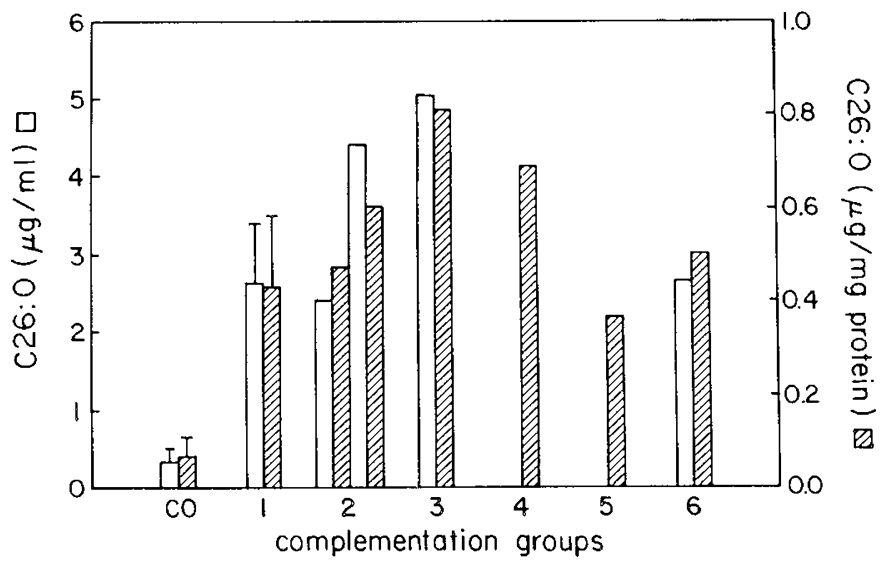

$\square$ plasma

Efibroblasts

Fig. 4. Level of very long chain fatty acids (C 26:0) in plasma and fibroblasts of patients in each complementation group (1-6). Values for control $(C o)$ and group 1 are given \pm SD.

enzyme catalyzing the first step of plasmalogen synthesis. Recently, Poll-The et al. (31) have demonstrated that complementing cell lines also acquire the capacity to oxidize phytanic acid. The data available so far suggest that these three indices of complementation are congruent and that an unequivocally positive result with any one of them can be taken as evidence that complementation has taken place.

The results presented here are consonant with studies reported previously by Brul et al. (13). These authors studied complementation in eight patients and also reached the conclusion that there was phenotypic heterogeneity among the complementation groups. Our groups 1 and 2 appear to be comparable to their groups 2 and 4 , respectively.

Our studies suggest that at least six genetically distinct mechanisms can lead to peroxisomal deficiency. Because only a small proportion of known cases have been tested in this way, it is possible, and even likely, that additional groups will be identified. It is important to define the relationship among the groupings represented here with those studied by other investigators. Efforts to accomplish this are in progress.

The identification of complementation groups per se provides the challenge of defining their specific defects. This task will be aided by recent advances in knowledge about the mechanisms that control normal peroxisomal biogenesis. As already noted, most peroxisomal enzymes contain topogenic sequences that target them to this organelle. The topogenic sequence for yeast acyl-CoA oxidase has been identified (32). Miyazawa et al. (33) have shown recently that a $\mathrm{COOH}$-terminal ser-lys-leu sequence is essential for the targeting of four rat peroxisomal enzymes. Brul et al. (34) have examined the kinetics of complementation and have shown that in some combinations of complementing cell lines complementation is particularly rapid and is unaffected by the addition of cycloheximide, an inhibitor of protein synthesis, whereas in the other three groups in which complementation took place more slowly, this agent abolished complementation. In the study of the mucopolysaccharidoses, the identification of complementation groups provided the impetus and pathway for the definition of the enzyme defects specific for each of these human disease states (35). It is hoped that analogous gains of knowledge will accrue from the complementation study of the disorders of peroxisomal biogenesis.

Acknowledgments. For permission to study their patients' cell lines we thank Drs. Derek A. Applegarth, Susan A. Berry, Neil R. M. Buist, Jan Friedman, William H. Ginther, Cheryl Greenberg, Stanley D. Johnsen, Bengt F. Kase, R. Kurz, Ronald N. Maclean, Wendy Mitchell, Steve Miller, John A. Phillips, III,
Irwin A. Schafer, Jon Wolff, and Hans Zellweger. We express special thanks to Drs. Hans Zellweger and Paul Lazarow for their review of the manuscript and valuable suggestions.

\section{REFERENCES}

1. Schutgens RBH, Heymans HSA, Wanders RJA, Van Den Bosch H, Tager JM 1986 Peroxisomal disorders: a newly recognized group of genetic diseases. Eur J Pediatr 144:430-440

2. Moser HW 1986 Peroxisomal Disorders. J Pediatr 108:89-92

3. Lazarow PB, Fujiki Y 1985 Biogenesis of Peroxisomes. Annu Rev Cell Biol $1: 489-530$

4. Santos MJ, Imanaka T, Shio H Small GM, Lazarow PB 1988 Peroxisomal membrane ghosts in Zellweger syndrome. Aberrant Organelle Assembly. Science 239:1536-1538

5. Santos MJ, Imanaka T, Shio H, Lazarow PJ 1988 Peroxisomal integral membrane proteins in control and Zellweger fibroblasts. J Biol Chem 263:10502-10509

6. Goldfischer S, Moore CL, Johnson AB, Spiro AJ, Valsamis MT, Wisniewski HK, Ritch RH, Norton WT, Rapin I, Gartner LM 1973 Peroxisomal and mitochondrial defects in the cerebro-hepato-renal syndrome. Science 182:62-64

7. Kelley RI 1983 The cerebrohepatorenal syndrome of Zellweger. Morphological and metabolic aspects. Am J Med Genet 16:503-517

8. Kelley RI, Datta NS, Dobyns WB, Hajra AK, Moser AB, Noetzel MJ, Zackai EH, Moser HW 1986 Neonatal adrenoleukodystrophy: New cases, biochemical studies and differentiation from Zellweger and related peroxisomal polydystrophy syndromes. Am J Med Genet 23:869-901

9. Gatfield PD, Taller E, Hinton G, Wallace AC, Abdelnour GM, Haust MD 1968 Hyperpipecolatemia: A new metabolic disorder associated with neuropathy and hepatomegaly. Can Med Assoc J 99:1215-1233

10. Poll-The BT, Saudubray JM, Ogier H, Schutgens RBH, Wanders RJA, Schrakamp G, Van Den Bosch H, Trybels JMF, Poulos A, Moser HW, Van Eldere J, Eyssen HJ 1986 Infantile Refsum's disease: Biochemical findings suggesting multiple peroxisomal dysfunction. J Inherited Metab Dis 9:169-174

11. Arias JA, Moser AB, Goldfischer SL 1985 Ultrastructural and cytochemical demonstration of peroxisomes in cultured fibroblasts from patients with peroxisome deficiency disorders. J Cell Biol 100:1789-1792

12. Lazarow PB, Moser HW Disorders of Peroxisome biogenesis. In: Scriver CR Beaudet AL, Sly WS, Valle D (eds) The Metabolic Basis of Inherited Disease, 6th ed. McGraw Hill Co, New York, In press.

13. Brul S, Westerfield A, Stijland A, Wanders RJA, Schram AW, Heymans HSA Schutgens RBH, Van Der Bosch H, Tager JM 1988 Genetic heterogeneity in the cerebro-hepato-renal (Zellweger) syndrome and other inherited disorders with a generalized impairment of peroxisomal functions: a study using complementation analysis. J Clin Invest 81:1702-1710

14. Roscher A, Hoefler S, Hoefler G, Paschke E, Paltauf F 1986 neonatal adrenoleukodystrophy (NALD) and cerebro-hepato-renal syndrome (CHRS): genetic complementation analysis of impaired peroxisomal plasmalogen biosynthesis. Abstract 24, Annual Symposium of the Society for the Study of Inborn Errors of Metabolism, Amersfoort, The Netherlands

15. Gravel RA, Mahoney MJ, Ruddle FH, Rosenberg LE 1975 Genetic complementation in heterokaryons of human fibroblasts defective in cobalmin metabolism. Proc Natl Acad Sci USA 72:3181-3185

16. Roels F, Goldfischer S 1979 Cytochemistry of human catalase: the demonstration of hepatic and renal peroxisomes by a high temperature procedure. Histochem Cytochem 27:1471-1477

17. Lazarow PB, Fujiki Y, Small GM, Watkins P, Moser H 1986 Presence of the peroxisomal 22-integral membrane protein in the liver of a person lacking recognizable peroxisomes (Zellweger syndrome). Proc Natl Acad Sci USA 83:9193-9196

18. Wolff J, Nyhan WL, Powell H, Takahashi D, Hutzler J, Hajra AK, Datta NS, Singh I, Moser HW 1986 Myopathy in an infant with a fatal peroxisomal disorder. Pediatr Neurol 2:141-166

19. Thomas GH, Haslam RHA, Batshaw ML, Capute AJ, Neidengard L, Ransom JL 1975 Hyperpipecolic acidemia associated with hepatomegaly, mental retardation, optic nerve dysplasia and progressive neurological disease. Clin Genet 8:376-382

20. Ek K, Kase BF, Reith A, Bjorkhem I, Pedersen JI 1986 Peroxisomal dysfunction in a boy with neurologic syndrome and amaurosis (Leber disease). Clinical and biochemical findings similar to those observed in Zellweger syndrome. J Pediatr 108:19-24

21. Budden SJ, Kennaway NG, Buist NRM, Poulos A, Weleber RG 1986 Dysmorphic syndrome with phytanic acid oxidase deficiency, abnormal very long chain fatty acids, and pipecolic acidemia: studies in four children. $\mathrm{J}$ Pediatr 108:33-39

22. Hermetter A, Paltauf F 1983 Procedures for the synthesis of ether lipids In Mangold HK, Paltauf F (eds) Ether Lipids: Biochemical and Biochemical Aspects Academic Press, New York, pp 389-420

23. Peters TJ, Muller M, deDuve C 1972 Lysosomes of the arterial wall 1. Isolation and subcellular fractionation of cells from normal rabbit aorta. J Exp Med 136:1117-1139

24. Lowry OH, Rosebrough NJ, Farr AL, Randall RJ 1951 Protein measurement with the Folic phenol reagent. J Biol Chem 193:265-275

25. Bradford MM 1976 A rapid and sensitive method for the quantitation of microgram quantities of protein using the principle of protein-dye binding. 
Anal Biochem 72:248-254

26. Moser HW, Moser AB, Frayer KK, Chen W, Schulman JD, O'Neile BP, Kishimoto Y 1981 Adrenoleukodystrophy: increased plasma content of saturated very long chain fatty acids. Neurology 31:1241-1249

27. Moser HW, Moser AB, Kawamura N, Murphy J, Suzuki K, Schaumburg H, Kishimoto Y, Milunsky A 1980 Adrenoleukodystrophy: elevated C26 fatty acid in cultured skin fibroblasts. Ann Neurol 7:542-549

28. Roscher A, Molzer B, Bernheimer H, Stockler S, Mutz I, Paltauf F 1984 The cerebrohepatorenal (Zellweger) syndrome: an improved method for the biochemical diagnosis and its potential value for prenatal detection. Pediatr Res 19:930-933

29. Pontecorvo G 1975 Production of mammalian somatic cell hybrids by means of polyethylene glycol treatment. Somat Cell Genet 1:397-400

30. Nelson V, Carey Wf 1985 A method for enrichment of hybrid somatic cells: complementation studies in certain enzymopathies. $J$ Inherited Metab Dis 8:95-99

31. Poll-The BT, Skjeldal OH, Stokke O, Poulos A, Demaugre F, Saudubray JM
1989 Phytanic acid alpha-oxidation and complementation analysis of classical Refsum and peroxisomal disorders. Hum Genet 81:175-181

32. Small GM, Szabo L, Lazarow PB 1988 Acyl-CoA oxidase contains two targeting sequences each of which can mediate protein import into peroxisomes EMBO J 7:1167-1173

33. Miyazawa S, Osumi T, Hashimoto T, Miura S, Ohno K, Fujiki Y 1989 Targeting signal of rat liver acyl-CoA oxidase locates at the extreme Cterminal. Mol Cell Biol 9:83-91

34. Brul S, Wiemer Eac, Westerveld A, Strijland A, Wanders RJA, Schram AW, Heymans HSA, Schutgens RBH, Van den Bosch H, Tager JM 1988 Kinetics of the assembly of peroxisomes after fusion of complementation cell lines from patients with the cerebro-hepato-renal (Zellweger syndrome and related disorders. Biochem Biophys Res Commun 152:1083-1089

35. McKusick VA, Neufeld EF 1983 The mucopolysaccharide storage diseases. In: Stanbury JB, Wyngaarden JB, Fredrickson DS, Goldstein JL, Brown MS (eds) The Metabolic Basis of Inherited Disease. McGraw Hill Book Co, New York, 5th ed, pp 751-777 